\title{
Expression of p53 gene in hepatocellular carcinomas induced by aflatoxin B1 with or without human hepatitis $B$ virus in tree shrews
}

\author{
Jianjia Su, ${ }^{1,2}$ Guozhong Qin, ${ }^{1}$ Ruiqi Yan, ${ }^{2}$ \\ Dingrui Huang, ${ }^{2}$ Chun Yang, ${ }^{2}$ Guohua Huang ${ }^{2}$ \\ and Prabhakar D. Lotlikar ${ }^{1,3}$ \\ 1 Fels Institute for Cancer Research and Molecular Biology and \\ Department of Biochemistry, Temple University School of Medicine, \\ 3420 North Broad Street, Philadelphia, PA 19140, USA \\ 2 Department of Pathology, Guangxi Cancer Institute, Nanning 530021, \\ Guangxi, China \\ 3 Corresponding author \\ Accepted 14 August 1997
}

Abbreviations: $\mathrm{HCC}$, hepatocellular carcinoma; $\mathrm{AFB}_{1}$, aflatoxin $\mathrm{B}_{1} ; \mathrm{HBV}$, hepatitis $B$ virus; HHBV, human HBV; DHBV, duck hepatitis B virus; WHV, woodchuck hepatitis virus; GSHV, ground squirrel hepatitis virus

\begin{abstract}
Using tree shrew as an animal model, our previous studies have demonstrated synergistic effects of aflatoxin $B_{1}\left(A F B_{1}\right)$ and human hepatitis $B$ virus (HHBV) in the induction of hepatocellular carcinoma (HCC). In the present study, we have examined expression of p53 gene in HCCs induced by $\mathrm{AFB}_{1}$ with or without HHBV infection in tree shrews. Avidinbiotin-peroxidase complex immunohistochemical method with human $\mathrm{p} 53-\mathrm{CM}_{1}$ polyclonal antibody has been used to detect $p 53$ expression in serial sections of paraffin-embedded liver and HCC tissues. Five out of 9 animals with HCCs (55.6\%) induced by $A_{1} B_{1}$ with $\mathrm{HHBV}$ infection and $2 / 3$ animals with HCCs $(66.7 \%)$ induced by $A^{2} B_{1}$ alone expressed the p53 protein. Out of $18 \mathrm{HCCs}$ examined, expression of p53 protein was observed in 9/10 moderately and poorly differ-entiated HCCs $(90.0 \%)$. None of the well differentiated HCCs (0/8) expressed p53 (0\%). Similarly, no p53 expression was observed in either non-tumorous or hyperplastic liver tissues or nodules. These results suggest that p53 expression associated with p53 mutation is a late event occurring probably during tumor progression in $A_{F} B_{1}$ and HHBV induced hepa-tocarcinogenesis in the tree shrew. This report is the first example of an experimental animal model where combination of human HBV and $\mathrm{AFB}_{1}$-induced HCCs demonstrate p53 expression.
\end{abstract}

Keywords: hepatocellular carcinoma; hepatitis B; aflatoxin $\mathrm{B}_{1}$; $\mathrm{p53}$ expression

\section{Introduction}

Hepatocellular carcinoma (HCC) is one of the world's most common cancers, occurring especially in Africa and South-East Asia (Beasley, 1982; Parkin et al., 1988). Epidemiological studies indicate that contamination of food with aflatoxin $B_{1}\left(A F B_{1}\right)$ and chronic infection with hepatitis $B$ virus (HBV) are the major risk factors for human liver cancer (Buendia, 1992; Ross et al., 1992; Yeh et al., 1989). Several investigations in different species of experimental animals have demonstrated synergistic effects of $\mathrm{AFB}_{1}$ and $\mathrm{HBV}$ in hepatocarcinogenesis (Sell et al., 1991; Cova et al., 1994; Bannasch et al., 1995). Thus, synergy between $\mathrm{HBV}$ expression and $\mathrm{AFB}_{1}$ hepatocarcinogenesis has been established in transgenic mice (Sell et al., 1991). In duck and woodchuck studies, in addition to $\mathrm{AFB}_{1}$, duck hepatitis $B$ virus (DHBV) and woodchuck hepatitis virus (WHB) were employed respectively as infectious agents (Bannasch et al., 1995; Cova et al., 1994).

p53, the tumor suppressor gene located on the short arm of chromosome 17 (Isobe et al., 1986) normally regulates the activity of the cell cycle machinery (Marx, 1993). Its gene product is critical for guarding the genome from incorporation of damaged DNA (Lane, 1992). Mutation of the $p 53$ gene has been observed with a high prevalence in diverse types of human cancers (Hollstein et al., 1991), and frequently occurs with point mutation in the coding sequence of tumor cellular gene. Mutation of $G$ to $T$ transversion at codon 249 position 3 of p53 gene has been detected in human $\mathrm{HCCs}$ associated with high exposure to $\mathrm{AFB}_{1}$ in Africa and in Qidong, China (Bressac et al., 1991; Hsu et al., 1991; Scorsone et al., 1992). The frequency of $p 53$ mutations in HCCs in different studies are variable from $18 \%$ to $67 \%$. However, these $p 53$ mutations are more frequent in $\mathrm{HBV}$-infected $\mathrm{HCC}$ patients exposed to $\mathrm{AFB}_{1}$ (Bressac et al., 1991; Goldblum et al., 1993; Hosono et al., 1993; Hsu et al., 1991; Livni et al., 1995; Nagao et al., 1995; Scorsone et al., 1992).

Using tree shrew (Tupaia glis) as an animal model, it was shown (Reddy et al., 1976) that feeding of AFB 1 to these animals produced HCCs in this species. On the basis of their results, we investigated the hepatocarcinogenesis of $\mathrm{AFB}_{1}$ and human HBV (HHBV) in this species (Yan et al., 1996a, 1996b). The results indicated that the $\mathrm{HCC}$ incidence was significantly higher in the tree shrews exposed to both $\mathrm{HHBV}$ and $A F B_{1}$ than in those which 
received either $\mathrm{HHBV}$ infection or $\mathrm{AFB}_{1}$ ingestion only. Thus, our data suggested a synergistic effect of HHBV and $\mathrm{AFB}_{1}$ in induction of HCCs in tree shrews. We have also examined expression of $p 53$ gene in various grades of HCCs of tree shrews using immunohistochemical method. These results suggest that p53 expression associated with $p 53$ mutation is a late event occurring probably during tumor progression in $\mathrm{AFB}_{1}$ and $\mathrm{HHBV}$ induced hepatocarcinogenesis in the tree shrew. This report is the first example of an experimental animal model where combination of human HBV and $\mathrm{AFB}_{1}$-induced $\mathrm{HCCs}$ demonstrate $\mathrm{p} 53$ expression.

\section{Materials and Methods}

\section{Animals and experimental design}

Carcinogenicity studies were carried out in China as described previously (Yan et al., 1996b). In brief, out of 80 adult tree shrews, $50 \%$ were inoculated with HHBV. All of these animals were then given either dimethyl sulfoxide or $\mathrm{AFB}_{1}$ dissolved in dimethyl sulfoxide added to the diet until the termination of the experiment. Several animals in both (HHBV + and HHBV -) groups died before 80th week without any signs of $\mathrm{HCC}$. First case of $\mathrm{HCC}$ was seen in one animal (HHBV + without $\left.\mathrm{AFB}_{1}\right)$ which died during 83rd week. The experiment was terminated at 158 weeks. The liver tissues of dead or sacrificed animals were fixed in $10 \%$ buffered formalin, then paraffin-embedded and were examined pathologically by hematoxylin and eosin staining. Thirteen animals developed HCCs. The tumor differentiation was classified according to Edmonson and Steiner (1954). The distribution of HCCs among various groups is indicated in Table 1. These paraffin-embedded liver tissues including $18 \mathrm{HCCs}$ induced in 12 animals have been examined for $p 53$ gene expression using immunohistochemistry.

\section{Chemicals}

Rabbit polyclonal antibody $\left(\mathrm{CM}_{1}\right)$ against human p53 protein and avidin-biotin-peroxidase complex kit (ABC kit) were purchased from Vector Laboratories Inc., Burlingame, CA. 3,3'-Diaminobenzidine was obtained from Sigma Chemical Co., St. Louis, MO. All other chemicals were of reagent grade.

\section{Immunohistochemistry}

p53 protein was detected using immunohistochemical staining according to published procedures (Shi et al., 1991; Resnick et al., 1995). In brief, formalin-fixed, paraffinembedded sections were deparaffinized in xylene and were passed through graded ethanol series. After quenching the endogenous peroxidase activity, sections were heated in a microwave oven followed with sequential treatment with normal goat serum, primary anti-p53 antibody $\left(\mathrm{CM}_{1}\right)(1: 800)$, biotinylated goat anti-rabbit immunoglobulin $\mathrm{G}(1: 200)$ and avidin-biotin-peroxidase complex. The sites of peroxidase binding were detected by the diaminobenzidine method. Sections of human colonic carcinoma with p53 expression were used as positive controls. Negative controls consisted of replacement of primary antibody with normal goat serum. The pattern of p53 nuclear expression was classified by estimating the percentage of stained tumor cells as follows:,$-<5 \%$ positive tumor cells; +, 6-10\% positive tumor cells;,++ 11 to $20 \%$ positive tumor cells;,+++ 21 to $50 \%$ positive tumor cells; and,$++++>50 \%$ positive tumor cells. We define a tumor as p53 positive if more than $5 \%$ of tumor cells showed nuclear p53 expression.

The significance of the data was statistically evaluated by using $X^{2}$ test.

\section{Results}

Thirteen animals developed HCCs throughout the experimental period of 158 weeks. The distribution of HCCs among various groups is shown in Table 1. The incidence of HCC in group A was significantly higher and statistically significant with a $\mathrm{P}$ value of $<0.05$ when compared with

Table 1. HCC development and p53 expression in various groups

\begin{tabular}{lccc}
\hline Group and Treatment & $\begin{array}{c}\text { No. of animals } \\
\text { surviving after } \\
83 r d w k\end{array}$ & $\begin{array}{c}\text { No. of animals } \\
\text { with HCCs (\%) }\end{array}$ & $\begin{array}{c}\text { p53 expression } \\
\text { among animals with } \\
\text { HCCs (\%) }\end{array}$ \\
\hline A (HHBV + AFB 1$)$ & 17 & $9(52.9)^{\mathrm{c}}$ & $5(55.6)$ \\
B (HHBV) & 9 & $1(11.1)^{\mathrm{a}}$ & $2(66.7)$ \\
C (AFB 1$)$ & $24^{\mathrm{b}}$ & $3(12.5)$ & \\
D (Control) & 8 & $0(0)$ & \\
\hline
\end{tabular}

\footnotetext{
a Not tested for p53 for lack of availability of tumor tissue.

b 19 cases were examined for $p 53$.

${ }^{\mathrm{C}}$ Statistically significant with $P<0.05$ when compared with groups $C$ and $D$.
} 
groups C and D. Fifty three samples of experimental tree shrew liver tissues were stained for the expression of p53 protein (Table 1). Since tumor tissue in group B was not available, it was not tested for $\mathrm{p} 53$ expression. The positive expression of p53 in HCC was $7 / 12$ (58.3\%), five animals in group $A$ and two in group $C$. There was, however, no statistical difference in the expression of p53 protein in groups A and C. No p53 immunostaining was observed in either nontumorous or hyperplastic liver tissues or nodules.

Positive p53 immunostaining was seen in nuclei of tumor cells but the intensity of staining was variable from cell to cell. Weak staining was sometimes seen in some tumorous cytoplasm.

Status of 12 cases of HCCs in regards to their size, grade of tumor and degree of p53 expression is presented in Table 2. Among 12 cases, $50 \%$ of animals had two nodules per animal. The expression of p53 protein in HCCs of tree shrews was related to the grades of tumor cells' histological differentiation. No positive expression of p53 protein was found in 8 HCCs which were Edmondson and Steiner's (1954) grade I in tumor cells' differentiation. All six grade II HCCs demonstrated p53 expression ranging between $10-22 \%$ of tumor cells positive for p53. Among 4 grade III HCCs, two showed high p53 expression (65-85\%), one showed low expression (10\%) and one without any p53 expression.

Results of grade and p53 expression of HCCs are summarized in Table 3 . Thus, 9 out of 10 cases of grade II-III tumors were positive for p53 staining whereas none were positive for $p 53$ staining among grade I tumors. These results are statistically significant with a $P$ value of $<0.005$.

\section{Discussion}

The synergistic effect of HBV infection and intake of $A F B_{1}$ has been suggested to be largely responsible for the high frequency of p53 mutations observed especially at the third base of codon 249 in human HCCs from Africa and China (Bressac et al., 1991; Hsu et al., 1991; Scorsone et al., 1992). Animal model systems have been employed to explore the relationship between mutations of $p 53$ in HCCs induced by either AFB 1 or/and hepadna viruses (Fujimoto et al., 1992; Hulla et al., 1993; Duflot et al., 1994; Rivkina et al., 1994). In contrast to human HCCs, no mutations at codon 249 were detected in HCCs induced by $\mathrm{AFB}_{1}$ in non-human primates. However, one mutation at the second base of codon 175 with a $G$ to $T$ transversion was observed in one HCC. On the basis of these

Table 2. Status of 12 cases of HCCs

\begin{tabular}{|c|c|c|c|c|c|c|c|c|c|c|c|}
\hline \multirow{3}{*}{$\begin{array}{l}\text { Animal } \\
\text { Number }\end{array}$} & \multirow{2}{*}{\multicolumn{2}{|c|}{ Treatment }} & \multirow{3}{*}{$\frac{\text { Survival Time }}{\text { wks }}$} & \multirow{3}{*}{ Tumor } & \multicolumn{2}{|c|}{$\mathrm{HCC}$} & \multirow{3}{*}{$\mathrm{p} 53^{\mathrm{b}}$} & \multirow{3}{*}{$\begin{array}{l}(\%) \\
\text { Positive } \\
\text { Cells }\end{array}$} & \multirow{2}{*}{\multicolumn{3}{|c|}{ In the Liver Cells }} \\
\hline & & & & & \multirow{2}{*}{$\begin{array}{l}\text { Size } \\
\mathrm{cm}\end{array}$} & \multirow[t]{2}{*}{ Grade $^{a}$} & & & & & \\
\hline & $\mathrm{HBV}$ & $\overline{\mathrm{AFB}_{1}}$ & & & & & & & $\mathrm{HbsAg}^{1}$ & $\mathrm{HBcAg}^{1}$ & $\overline{H B V} \mathrm{DNA}^{2}$ \\
\hline 2644 & - & + & 88 & $\mathrm{~T} 1$ & 3.2 & III & + & $(10 \%)$ & - & - & - \\
\hline 3057 & + & + & 115 & $\mathrm{~T} 1$ & 1.2 & I & - & & - & + & + \\
\hline \multirow[t]{2}{*}{3050} & + & + & 120 & $\mathrm{~T} 1$ & 0.6 & III & ++++ & $(85 \%)$ & + & - & + \\
\hline & & & & $\mathrm{T} 2$ & 2.4 & III & ++++ & $(65 \%)$ & + & - & + \\
\hline 2956 & + & + & 123 & $\mathrm{~T} 1$ & 1.8 & II & +++ & $(22 \%)$ & - & - & + \\
\hline \multirow[t]{2}{*}{3073} & + & + & 125 & $\mathrm{~T} 1$ & 0.8 & I & - & & + & - & + \\
\hline & & & & $\mathrm{T} 2$ & 3.2 & II & ++ & $(12 \%)$ & + & - & + \\
\hline \multirow[t]{2}{*}{3019} & + & + & 126 & $\mathrm{~T} 1$ & 0.3 & I & - & & + & + & + \\
\hline & & & & $\mathrm{T} 2$ & 0.4 & I & - & $(4 \%)$ & + & + & + \\
\hline 3052 & - & + & 132 & $\mathrm{~T} 1$ & 0.5 & III & - & & - & - & - \\
\hline \multirow[t]{2}{*}{3072} & + & + & 137 & $\mathrm{~T} 1$ & 0.8 & I & - & & + & - & + \\
\hline & & & & $\mathrm{T} 2$ & 1.3 & I & - & $(3 \%)$ & + & - & + \\
\hline \multirow[t]{2}{*}{3077} & + & + & 137 & $\mathrm{~T} 1$ & 2.1 & II & ++ & $(20 \%)$ & + & - & + \\
\hline & & & & $\mathrm{T} 2$ & 1.5 & II & ++ & $(20 \%)$ & + & - & + \\
\hline 3070 & + & + & 142 & $\mathrm{~T} 1$ & 0.7 & II & ++ & $(15 \%)$ & + & - & + \\
\hline \multirow[t]{2}{*}{3071} & + & + & 142 & $\mathrm{~T} 1$ & 1.4 & I & - & & - & + & + \\
\hline & & & & $\mathrm{T} 2$ & 1.7 & I & - & $(3 \%)$ & - & + & + \\
\hline 2847 & - & + & 158 & $\mathrm{~T} 1$ & 1.5 & II & + & $(10 \%)$ & - & - & - \\
\hline
\end{tabular}

\footnotetext{
${ }^{a}$ Grade of HCC differentiation was classified according to Edmondson and Steiner (1954).

${ }^{b}$ Degree of p53 nuclear expression in HCC was graded as follows: -, $<5 \%$ positive tumor cells; +, 6 to $10 \%$ positive tumor cells; ++, 11 to $20 \%$ positive tumor cells; +++, 21 to $50 \%$ positive tumor cells; ++++, $>50 \%$ positive tumor cells. We define a tumor as p 53 positive if more than $5 \%$ of the tumor cells showed nuclear p53 expression.

${ }^{1}$ Unpublished data (Su, J. J., Huang, D. R., Yang, C., Huang, G. H. and Yan, R. Q.).

${ }^{2}$ Data from Su et al. (1991).
} 
Table 3. Comparison of p53 positivity in different grades of HCCs

\begin{tabular}{ccl}
\hline Grade of HCCs & No. of HCCs & $\begin{array}{c}\text { No. of HCCs positive } \\
\text { for p53 }(\%)^{\mathrm{a}}\end{array}$ \\
\hline I & 8 & $0(0)$ \\
II-III & 10 & $9(90)^{\mathrm{b}}$ \\
Total & 18 & $9(50.0)$ \\
\hline
\end{tabular}

a $A$ tumor is defined as $p 53$ positive if more than $5 \%$ of the tumor cells show nuclear p53 expression.

b Data statistically significant with $P<0.005$ when compared with those of grade I tumors.

data, it was suggested that HBV may be a prerequisite for $\mathrm{AFB}_{1}$ induction of codon 249 mutation (Fujimoto et al., 1992). In the rat, $\mathrm{AFB}_{1}$-induced preneoplastic hepatic nodules did not demonstrate any p53 gene mutation at the site corresponding to codon 249 of the human $p 53$ gene (Hulla et al., 1993). Similarly, there was no presence of $p 53$ gene mutation at 249 codon in HCCs produced in domestic ducks in Qidong, China, irrespective whether these ducks were DHBV positive or negative and treated or not treated with $\mathrm{AFB}_{1}$ (Duflot et al., 1994). In another study, a mutation of $p 53$ gene was detected in only one out of five ground squirrel HCCs where these animals were GSHV positive and treated with $\mathrm{AFB}_{1}$. This mutation was at the second base of codon 176 with a $G$ to $T$ transversion. Hepatocellular carcinomas in two ground squirrels without $\mathrm{AFB}_{1}$ treatment and $11 \mathrm{HCCs}$ in woodchucks persistently infected with WHV were not mutated in the p53 gene (Rivkina et al., 1994).

In the present study, immunohistochemical detection of p53 protein has been used as a surrogate marker for missense mutation due to following reasons: 1) Mutant p53 proteins are more stable than the wild type and thus their accumulation can be detected immunohistochemically (Oren, 1992). 2) Immunohistochemical detection of p53 expression has been shown to be a very reliable indicator of p53 mutations in several human cancers including HCCs (Hsu et al., 1993; Dowell and Hall, 1994; $\mathrm{Ng}$ et al., 1994; Ojanguren et al., 1995; Vet et al., 1995). Even though rabbit polyclonal antibody $\left(\mathrm{CM}_{1}\right)$ raised against human wild-type and mutant $p 53$ has been used in the present study, this antibody reacted only with p53 present in grades II and III HCCs produced in tree shrews fed $\mathrm{AFB}_{1}$ with or without human HBV infection. There was no expression of p53 protein in either non-tumorous or hyperplastic liver tissues or nodules of these animals. Similarly, there was no detection of p53 expression in low grade I, well-differentiated HCCs. Like the present study, cross reactivity of antibody raised against human p53 and hamster pancreatic adenocarcinoma p53 has also been reported recently (Chang et al., 1994).

Data reported in the present study indicate that even though $50 \%$ of animals bearing HCCs had two tumors, the grade of a tumor determined the p53 expression of that tumor. Thus, well-differentiated (Grade I) HCCs showed no positive p53 expression whereas moderately differentiated (Grade II) HCCs showed p53 expression with 10-22\% positive cells and some poorly differentiated Grade III HCCs with p53 expression as high as $65-85 \%$ positive cells. These results indicating that p53 expression associated with $p 53$ mutation is a late event occurring probably during tumor progression of hepatocarcinogenesis in the tree shrew are compatible with data obtained with human HCCs (Oda et al., 1992; Hsu et al., 1993; Tanaka et al., 1993; Hsu et al., 1994; Nagao et al., 1995; Ojanuren et al., 1995). The overall data and no or low expression of p53 in HCCs induced in animals given only $\mathrm{AFB}_{1}$ in the present study suggest that $\mathrm{HHBV}$ infection has a synergistic effect not only on $\mathrm{AFB}_{1}$-induced $\mathrm{HCC}$ s but also on p53 expression. On the basis of our immunohistochemical data, it appears that $50 \%$ HCCs induced in tree shrews with $\mathrm{AFB}_{1}$ and with or without HHBV infection show p53 mutation. Rates of $p 53$ mutations in HCCs produced in other experimental animals treated with $\mathrm{AFB}_{1}$ alone or with hepadna viruses are much lower (Fujimoto et al., 1992; Hulla et al., 1993; Duflot et al., 1994; Rivkina et al., 1994) than those reported in the present study. These differences in p53 mutations may be species specific. On the other hand, on the basis of our present data and those reported with human HCCs (Oda et al., 1992; Hsu et al., 1993; Tanaka et al., 1993; Hsu et al., 1994; $\mathrm{Ng}$ et al., 1994; Nagao et al., 1995; Ojanguren et al., 1995), it appears that low p53 mutation rates observed in HCCs induced in ground squirrels may be due to examination of only low grade (well-differentiated) HCCs (Rivkina et al., 1994). In addition, experimental tree shrews in the present study were inoculated with human serum containing human HBV. Although, HHBV as well as WHV, GSHV and DHBV belong to hepadnavirus family, there are some differences in their molecular structures. For example, DHBV differs from $\mathrm{HHBV}$ such that is lacks the $\mathrm{X}$ gene and it induces only mild liver tissue disease in its host (Mandart et al., 1984). However, WHV appears to be more oncogenic than HBV (Popper et al., 1987; Buendia, 1992). There may be additional differences in infectivity and oncogenicity among these hepadnaviruses.

Our previous studies (Su et al., 1992) and recent studies from another laboratory (Walter et al., 1996) have demonstrated that HHBV was not only replicated in liver cells but was also integrated into liver cell DNA of the tree shrew. It has been shown recently that HHBV $x$ protein plays an important role in the pathogenesis of early human HCC by interaction with p53 protein (Zhu et al., 1993). Recent studies also suggest that functional inactivation of $p 53$ gene product but not structural mutation of $p 53$ is responsible for liver cancer causation (Ueda et al., 1995). In view of these recent developments, it is important to explore further our p53 studies in HCCs induced in tree 
shrews by $\mathrm{HHBV}$ and $\mathrm{AFB}_{1}$ by examining $p 53$ gene by its amplification by polymerase chain reaction (PCR) and sequence analysis of purified PCR product.

Tree shrews (Tupaia glis), squirrel-like mammals occurring throughout Southeast Asia and once considered to be a non-human primate have been colonized successfully (Morris et al., 1967). They have been reclassified as Scandentia (Novak, 1991) and are closer to the primates. Since tree shrew has a shorter life span compared to primates and is small, it is an ideal animal for experimental use. On the basis of our studies, it appears that tree shrew is an ideal animal to study the mechanism of HCC development. Data generated with this species may be extrapolated to humans.

\section{Acknowledgements}

We are indebted to Israel Beauchamps for expert assistance in preparation of this manuscript.

\section{References}

Bannasch, P., Khoshkhou, N. I., Hacker, H. J., Radaeva, S., Mrozek, M., Zillman, U., Kopp-Schneider, A., Haberkorn, U., Elgas, M., Tolle, T., Roggendorf, M. and Toshkov, I. (1995) Synergistic hepatocarcinogenic effect of hepadnaviral infection and dietary aflatoxin $\mathrm{B}_{1}$ in woodchucks. Cancer Res. 55: 3318-3330

Beasley, R. P. (1982) Hepatitis B virus as the etiologic agent in hepato-cellular carcinoma: epidemiologic considerations. Hepatology 2: 21S-26S

Bressac, B., Kew, M., Wands, J. and Ozturk, M. (1991) Selective G to T mutations of p53 gene in hepatocellular carcinoma from Southern Africa. Nature 350: 429-431

Buendia, M. A. (1992) Hepatitis B virus and hepatocellular carcinoma. Adv. Cancer Res. 59: $167-226$

Chang, K. W., Mangold, K. A., Hubchak, S., Laconi, S. and Scarpelli, D. G. (1994) Genomic $p 53$ mutation in a chemically induced hamster pancreatic ductal adenocarcinoma. Cancer Res. 54: 3878-3883

Cova, L., Mehrotra, R., Wild, C. P., Chutimataewin, S., Cao, S. F., Duflot, A., Prave, M., Yu, S. Z., Montesano, R. and Trepo, C. (1994) Duck hepatitis B virus infection, aflatoxin B 1 and liver cancer in domestic Chinese ducks. Br. J. Cancer 69: 104-109

Dowell, S. P. and Hall, P. A. (1994) The clinical relevance of the p53 tumor suppressor gene. Cytopatholology 5: 133-145

Duflot, A., Hollstein, M., Mehrotra, R., Trepo, C., Montesano, R. and Cova, L. (1994) Absence of $p 53$ mutation at codon 249 in duck hepatocellular carcinomas from the high incidence area of Qidong (China). Carcinogenesis 15: 1353-1357

Edmondson, H. A. and Steiner, P. E. (1954) Primary carcinoma of the liver: a study of 100 cases among 48,900 necropsies. Cancer (Phila) 7: 462-503

Fujimoto, Y., Hampton, L. L., Luo, L. D., Wirth, P. J. and Thorgeirsson, S. S. (1992) Low frequency of $p 53$ gene mutation in tumors induced by aflatoxin $B_{1}$ in nonhuman primates. Cancer Res. 52: 1044-1046

Goldblum, J. R., Bartos, R. E., Carr, K. A. and Frank, T. S. (1993) Hepatitis B and alterations of the $p 53$ tumor suppressor gene in hepatocellular carcinoma. Am. J. Surg. Pathol. 17: 1244-1251

Hollstein, D., Sidransky, D., Vogelstein, B. and Harris, C. C. (1991) P53 mutation in human cancers. Science 253: 49-53

Hosono, S., Chou, M. J., Lee, C. S. and Shih, C. (1993) Infrequent mutation of p53 gene in hepatitis B virus positive primary hepatocellular carcinomas. Oncogene 8: 491496

Hsu, I. C., Metcalf, R. A., Sun, T., Welsh, J. A., Wang, N. J. and Harris, C. C. (1991). Mutational hotspot in the $p 53$ gene in human hepatocellular carcinomas. Nature 350 : $427-428$

Hsu, H. C., Tseng, H. J., Lai, P. L., Lee, P. H. and Peng, S. Y. (1993) Expression of p53 gene in 184 unifocal hepatocellular carcinomas. Association with tumor growth and invasiveness. Cancer Res. 53: 4691-4694

Hsu, H. C., Peng, S. Y., Lai, P. L., Chu, J. S. and Lee, P. H. (1994) Mutations of p53 gene in hepatocellular carcinoma (HCC) correlate with tumor progression and patient prognosis: A study of 138 patients with unifocal HCC. Int. J. Oncol. 4: 1341-1347

Hulla, J. E., Chen, Z. Y. and Eaton, D. L. (1993) Aflatoxin B1-induced rat hepatic hyperplastic nodules do not exhibit a site-specific mutation within the $p 53$ gene. Cancer Res. 53: 9-11

Isobe, M., Emanuel, B. S. and Givol, D. (1986) Localization of gene for human p53 tumor antigen to band 17p13. Nature 320: 84-85

Lane, D. P. (1992) P53, guardian of the genome. Nature 358: 15-16

Livni, N., Eid, A., Ilan, Y., Rivkind, A., Rosenmann, E., Blendis, L. M., Shouval, D. and Galun, E. (1995) P53 expression in patients with cirrhosis with and without hepatocellular carcinoma. Cancer 75: 2420-2426

Mandart, E., Kay, A. and Galibert, F. (1984) Nucleotide sequence of a cloned duck hepatitis $B$ virus genome: comparison with woodchuck and human hepatitis $B$ virus sequence. J. Virol. 49: 782-792

Marx, J. (1993) How p53 suppresses cell growth. Science 262: 1644-1645

Morris, J. H., Negus, N. C. and Spertzel, R. O. (1967) Colonization of the Tree Shrew (Tupaia glis). Lab. Cen. Care 17: 514-520

Nagao, T., Kondo, F., Sato, T., Nagato, Y. and Kondo, Y. (1995) Immuno-histochemical detection of aberrant p53 expression in hepatocellular carcinoma: Correlation with cell proliferative activity indices including mitotic index and MIB-1 immunostaining. Hum. Pathol. 26: 326-333

Ng, I. O. L., Srivastana, G., Chung, L. P., Tsang, S. W. Y. and Ng, M. M. T. (1994) Overexpression and point mutations of $p 53$ tumor suppressor gene in hepatocellular carcinomas in Hong Kong Chinese people. Cancer Res. 74: 30-37

Nowak, R. M. (1991) Walker's Mammals of the World, 5th Edn., Vol. 1, The Johns Hopkins University Press, Baltimore

Oda, T., Tsuda, H., Scarpa, A., Sakamoto, M. and Hirohashi, S. (1992) Mutation pattern of the $p 53$ gene as a diagnostic marker for multiple hepatocellular carcinoma. Cancer Res. 52: 3674-3678

Ojanguren, I., Ariza, A., Castella, E. M., Fernandez-Vasalo, A., Mate, J. L. and NavasPalacios, J. J. (1995) p53 immunoreactivity in hepatocellular adenoma, focal nodular hyperplasia, cirrhosis and hepatocellular carcinoma. Histopathology 26: 63-68

Oren, M. (1992) p53: The ultimate tumor suppressor gene? FASEB J. 6: 3169-3176

Parkin, D. M., Laara, E. and Muir, C. S. (1988) Estimates of the world wide frequency of sixteen major cancers. Int. J. Cancer 41: 184-197

Popper, H., Roth, L., Purcell, R. H., Tennant, B. C., and Gerin, J. L. (1987) Hepatocarcinogenicity of the woodchuck hepatitis virus. Proc. Natl. Acad. Sci. USA 84: $866-870$

Reddy, J. K., Svoboda, D. J. and Rao, M. S. (1976) Induction of liver tumors by aflatoxin $\mathrm{B}_{1}$ in tree shrew (Tupaia glis). A nonhuman primate. Cancer Res. 36: 151-160

Resnick, J. M., Cheuwitz, D., Knapp, D., Uhlman, D. and Niehans, G. A. (1995) A microwave method that enhances detection of aberrant p53 expression in formalinfixed, paraffin-embedded tissues. Arch Pathol. Lab. Med. 119: 360-366

Rivkina, M. B., Cullen, J. M., Robinson, W. S. and Marion, P. L. (1994) State of the p53 gene in hepatocellular carcinomas of ground squirrels and woodchucks with past and 
ongoing infection with hepadnaviruses. Cancer Res. 54: 5430-5437

Ross, R. K., Yuan, J. M., Yu, M. C., Wogan, G. N., Qian, G. S., Tu, J. T., Groopman, J. D., Gao, Y. T. and Henderson, B. E. (1992) Urinary aflatoxin biomarkers and risk of hepatocellular carcinoma. Lancet. 339: 943-946

Scorsone, K. A., Zhou, Y. Z., Butel, J. S. and Slagle, B. L. (1992) P53 mutations cluster at codon 249 in hepatitis B virus-positive hepatocellular carcinomas from China. Cancer Res. 52: 1635-1638

Sell, S., Hunt, J. M., Dunsford, H. A. and Chisari, F. V. (1991) Synergy between hepatitis $B$ virus expression and chemical hepatocarcinogens in transgenic mice. Cancer Res. 51: 1278-1285

Shi, S. R., Key, M. E. and Kalra, K. L. (1991) Antigen retrieval in formalin-fixed, paraffinembedded tissues: An enhancement method for immuno-histochemical staining based on microwave oven heating of tissue section. J. Histochem. Cytochem. 39: 741-748

Su, J. J., Lou, D., Huang, D. R., Huang, G. H., Young, C. and Yan, R. Q. (1991) A study on the relationship among $\mathrm{HBV}$ infection, $\mathrm{AFB}_{1}$ intake and the development of primary liver cancer in tree shrews by in situ hybri-dization techniques. Acta Guangxi Med. College(China) 8: 169-173

Su, J. J., Wong, Y., Yang, C. and Huang, D. R. (1992) Human hepatitis B virus DNA integration with the gene of liver cells in tree shrews infected by HHBV. Chinese $J$. Pathol. 21: 308-309

Tanaka, S., Toh, Y., Adachi, E., Natsumata, T., Mori, R. and Sugimachi, K. (1993) Tumor progression in hepatocellular carcinoma may be mediated by p53 mutation. Cancer Res. 53: 2884-2887

Ueda, H., Ullrich, S. J., Guangemi, J. D., Kappel, C. A., Ngo, L., Feitelson, M. A. and Jay, G. (1995) Functional inactivation but not structural mutation of $p 53$ causes liver cancer. Nat. Genet. 9: 41-47

Vet, J. A. M., Bringuier, P. P., Schaafsma, H. E., Witjes, J. A., Debruyne, F. M. J. and Schalken, J. A. (1995) Comparison of p53 protein over-expression with p53 mutation in bladder cancer: Clinical and biological aspects. Lab. Invest. 73: 837-843

Walter, E., Keist, R., Niederost, B., Pult, I. and Blum, H. E. (1996) Hepatitis B virus infection of Tupaia hepatocytes in vitro and in vivo. Hepatology 24: 1-5

Yan, R. Q., Su, J. J., Huang, D. R., Gan, Y. C., Yang, C. and Huang, G. H. (1996a) Human hepatitis $B$ virus and hepatocellular carcinoma. I. Experimental infection of tree shrews with hepatitis B virus. J. Cancer Res. Clin. Oncol. 122: 283-288

Yan, R. Q., Su, J. J., Huang, D. R., Gan, Y. C., Yang, C. and Huang, G. H. (1996b) Human hepatitis $B$ virus and hepatocellular carcinoma. II. Experi-mental induction of hepatocellular carcinoma in tree shrews exposed to hepatitis $B$ virus and aflatoxin $B_{1} . J$. Cancer Res. Clin. Oncol. 122: 289-295.

Yeh, F. S., Yu, M. C., Mo, C. C., Luo, S., Tong, M. J. and Henderson, B. E. (1989) Hepatitis B virus, aflatoxins, and hepatocellular carcinoma in Southern Guangxi, China. Cancer Res. 49: 2506-2509

Zhu, M., London, W. T., Duan, L. X. and Feitelson, M. A. (1993) The value of hepatitis Bx antigen as a prognostic marker in the development of hepatocellular carcinoma. Int J. Cancer 55: 571-576 